\title{
モータ中性線を利用したパッシブEMIフィルタ 一放熱フィンからの漏れ電流の抑制効果一
}

\author{
学生員 堂元 貴史* 正 員 赤木 泰文*
}

\begin{abstract}
A Passive EMI Filter with Access to the Ungrounded Motor Neutral Line -Its Effect on Eliminating Leakage Current from the Inverter Heat Sink-
\end{abstract}

Takafumi Doumoto*, Student Member, Hirofumi Akagi*, Member

\begin{abstract}
This paper deals with a leakage current flowing out of the heat sink of a voltage-source PWM inverter. The heat-sink leakage current is caused by a steep change in the common-mode voltage produced by the inverter. It flows through parasitic capacitors between the heat sink and power semiconductor devices when no EMI filter is connected. Experimental results reveal that the heat-sink leakage current flows not into the supply side, but into the motor side. These understandings succeed in describing an equivalent common-mode circuit taking the parasitic capacitors into account. The authors have proposed a passive EMI filter that is unique in access to the ungrounded motor neutral line. It is discussed from this equivalent circuit that the passive EMI filter is effective in preventing the leakage current from flowing. Moreover, installation of another small-sized common-mode inductor at the ac side of the diode rectifier prevents the leakage current from flowing into the supply side. Experimental results obtained from a 200-V, 3.7-kW laboratory system confirm the effectiveness and viability of the EMI filter.
\end{abstract}

キーワード : コモンモード電圧, 漏れ電流, モータ中性線, パッシブ EMI フィルタ, 電圧形インバータ

Keywords: Common-mode voltage, leakage current, motor-neutral line, passive EMI filter, voltage-source inverter

\section{1.はじめに}

三相電圧形 PWM インバータは , モータ駆動用インバー タとして広く使用されている。しかし，このインバータの 出力相電圧の総和は零にならない。このことはコモンモー ド電圧の発生を意味し，モータ軸電圧や高周波漏れ電流など の問題を誘発する。モータフレーム・軸の間に生じるモー 夕軸電圧は, ベアリングの寿命を縮めるベアリング電流の 原因になる。モータ巻線とフレーム間の浮遊容量を通して 流れる漏れ電流やインバータの放熱フィンから流出する漏 れ電流は, 漏電遮断器の誤動作を引き起こし , 伝導性 EMI (Electro-Magnetic Interference) や放射性 EMI の原因にも なる。これらは PWM 周波数の高周波化とスイッチングが 高速化するにつれて顕在化する傾向にある ${ }^{(1)}$ (4)。

従来, パワーエレクトロニクス機器の EMI 対策として, リアクトルやコンデンサを用いたパッシブ EMI フィルタが 用いられてきた ${ }^{(5)(6)}$ 。筆者らは先に, 相電圧と線間電圧を同

\footnotetext{
* 東京工業大学 大学院理工学研究科 電気電子工学専攻

干 152-8552 東京都目黑区大岡山 2-12-1, S3-17

Department of Electrical and Electronics Engineering, Tokyo Institute of Technology

S3-17, 2-12-1, O-okayama, Meguro-ku, Tokyo 152-8552
}

時に正弦波化するパッシブ EMI フィルタ (7) やモータ中性 線を利用したパッシブ EMI フィルタ ${ }^{(8)(9)}$ を提案した。

しかし，これらはモータからの漏れ電流の抑制について 検討したものであり, 放熱フィンからの漏れ電流を検討し た論文は少ない(10)(11)。文献 (10)では, 放熱フィンからの漏 れ電流の発生機構を明らかにし, リアクトルや抵抗を使用し て放熱フィンを接地することを提案している。しかし，イ ンバータフレームと放熱フィンを一体化した汎用インバー タの場合には, リアクトルや抵抗を介して放熱フィンを接 地することは不可能に近い。

本論文では, 放熱フィンからの漏れ電流に注目し，モータ 中性線を利用したパッシブEMI フィルタの抑制効果を検討 する。具体的には, まず放熱フィンからの漏れ電流の流出 経路を明らかにし，等価回路を導出する。次に，この等価回 路からモータ中性線を利用したパッシブ EMI フィルタが， 放熱フィンからの漏れ電流の抑制に有効であることを理論 的に説明し，実験的に光の有効性を確認する。さらに，ダ イオード整流器の交流側に小容量コモンモードチョークを 接続することによって, 放熱フィンからの漏れ電流やモー タからの漏れ電流を実用上問題にならない程度まで抑制で きることを実験的に示す。 


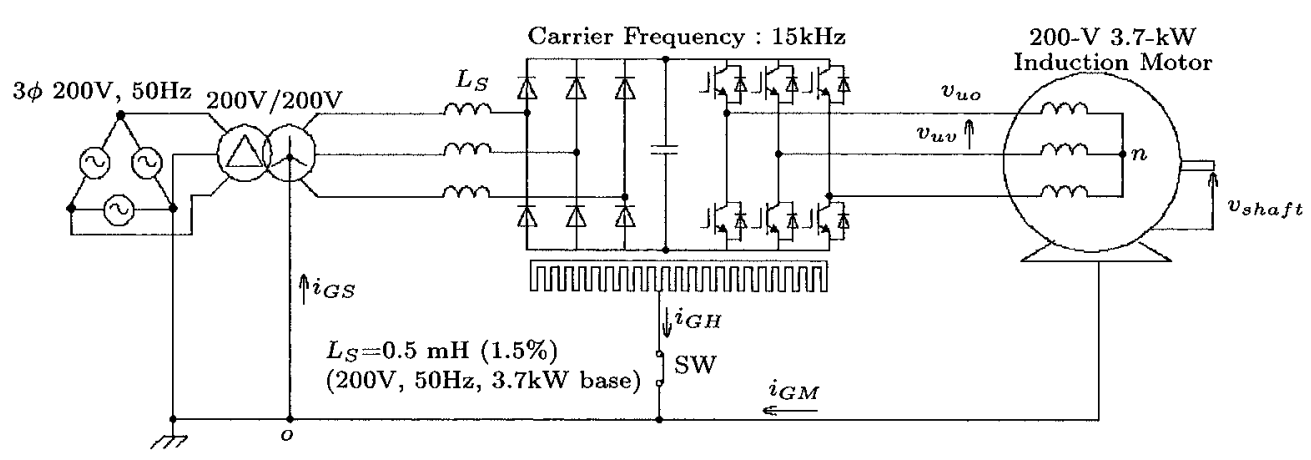

図 1 インバータとモータを直結した場合の実験システム構成

Fig. 1. An experimental system configuration when no EMI filter is connected.

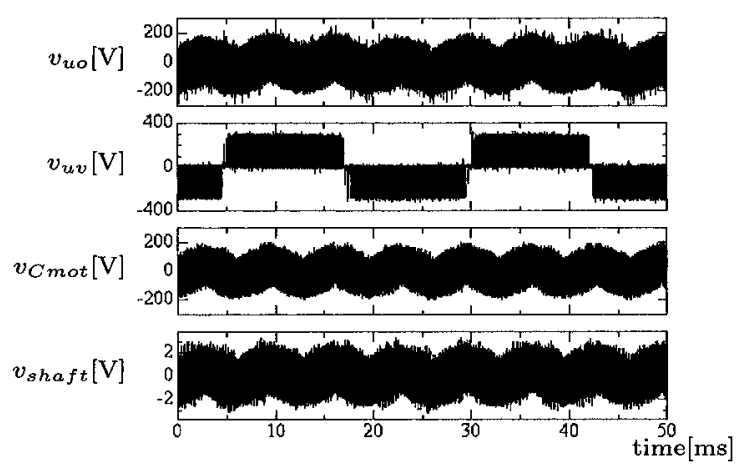

(a) Output-frequency-based time scale

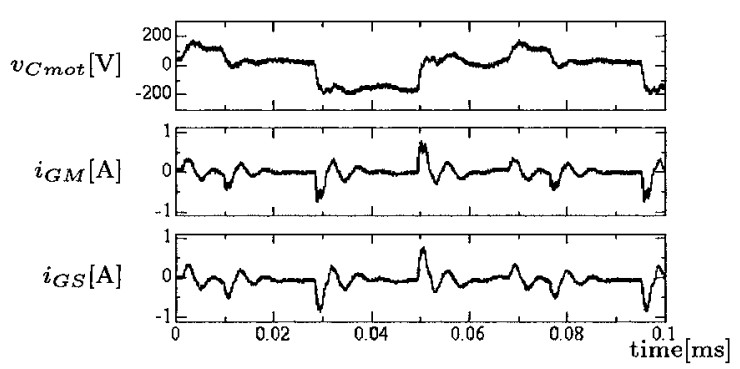

(b) Carrier-frequency-based time scale

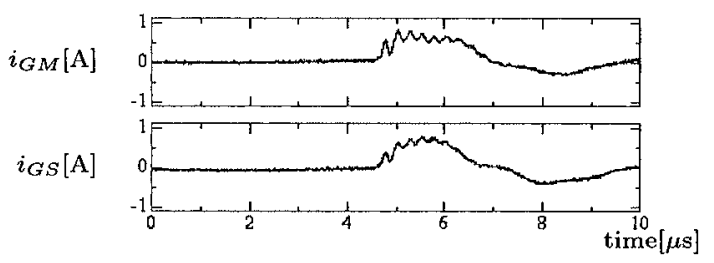

(c) Close-up waveforms of (b)

图 2 インバータとモータを直結し, 放熱フィン を非接地にした場合の実測波形

Fig. 2. Experimental waveforms when no EMI filter is connected, and the heat sink is ungrounded.

\section{2. 放熱フィンからの漏れ電流の実測波形}

图 1 にインバータ (容量 $5 \mathrm{kVA}$,キャリア周波数 $15 \mathrm{kHz}$ ) と誘導電動機 $(200 \mathrm{~V}, 3.7 \mathrm{~kW}, 4$ 極) を直結した場合のシ ステム構成を示す。図 2 は SW をオフにして放熱フィンを 非接地にした場合，図 3 はSW をオンにして放熱フィンを 接地した場合の実測波形である。実験では，インバータを

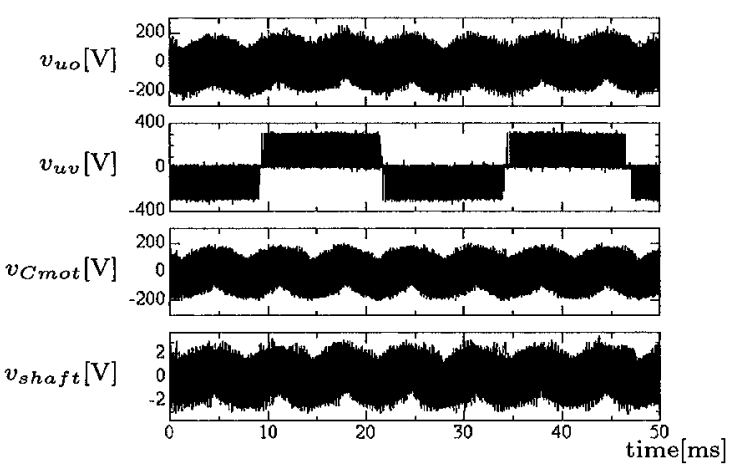

(a) Output-frequency-based time scale

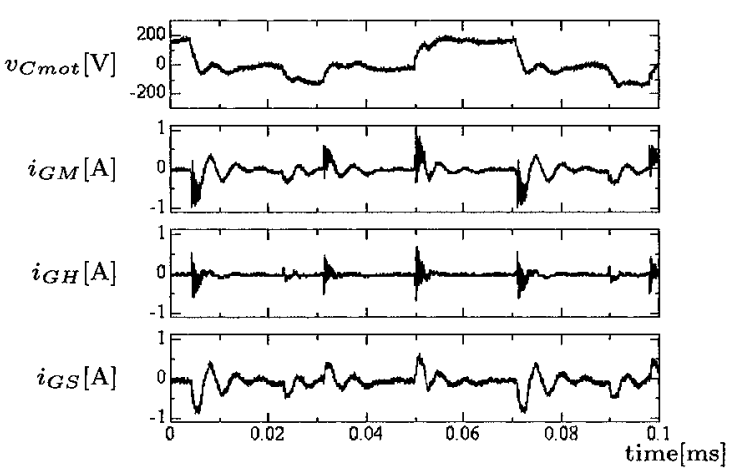

(b) Carrier-frequency-based time scale

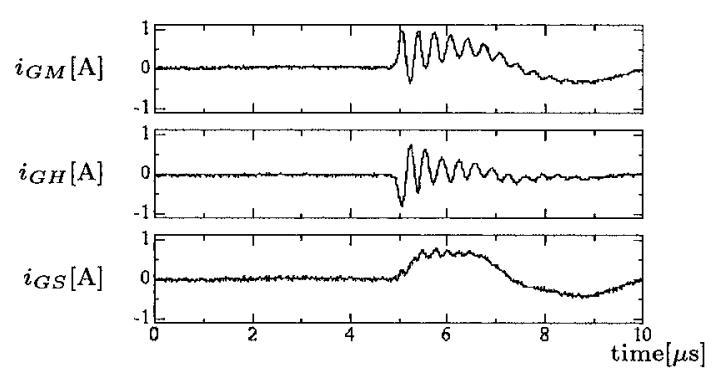

(c) Close-up waveforms of (b)

図 3 インバータとモータを直結し，放熱フィン を接地した場合の実測波形

Fig. 3. Experimental waveforms when no EMI filter is connected, and the heat sink is grounded.

$V / f$ 一定制御，キャリア周波数 $15 \mathrm{kHz}$, 出力周波数 $40 \mathrm{~Hz}$ に設定し, 誘導電動機は無負荷で運転した。相電圧 $v_{u o}$, 線 間電圧 $v_{u v}$ には大きなスイッチングリプルが含まれている 
ことがわかる。相電圧 $v_{u o}$, モ一タ端子でのコモンモード電 圧 $v_{C m o t}$ にはダイオード整流器のコモンモード電圧 $v_{\text {Crec }}$ に よる $150 \mathrm{~Hz}$ 成分 ${ }^{(9)}$ が含まれている。軸電圧 $v_{\text {shaft }}$ にはス イッチングリプルによる高周波成分とダイオード整流器の コモンモード電圧 $v_{\text {Crec }}$ による $150 \mathrm{~Hz}$ 成分が存在し, ピー

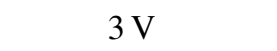

モータからの漏れ電流 $i_{G M}$ および放熱フィンからの漏れ 電流 $i_{G H}$ は, モータ浮遊容量およびパワーデバイスの浮遊 容量を介して流れるため, ともにモータのコモンモード電 圧 $v_{C m o t}$ の微分波形になっている。放熱フィンを接地する と, 放熱フィンからの漏れ電流 $i_{G H}$ およびモータからの漏 れ電流 $i_{G M}$ に約 $3 \mathrm{MHz}$ の高周波振動成分が含まれている が，これらの高周波振動成分は互いに逆位相である。しか し，これらの高周波振動成分は放熱フィンを非接地にした 場合には発生していない。一方, 電源変圧器中性線の電流 $i_{G S}$ は放熱フィンの接地·非接地に関係なく同じ波形であ り，200 kHz 成分を含むが $3 \mathrm{MHz}$ の高周波振動成分は存在 しない。

\section{3. コモンモードに対する等価回路の導出}

〈3. 1〉放熱フィンの電位変動の測定中小容量の汎用 インバータでは,ダイオード整流器モジュールとインバータ モジュールが共通の放熱フィンに取り付けられることが多 い。弚のため, ダイオード整流器が発生するコモンモード 電圧 $v_{C r e c}$ とインバータが発生するコモンモード電圧 $v_{\text {Cinv }}$ によって放熱フィンの電位は変動する。

図 4(a) は, ダイオード整流器が発生するコモンモード電 圧 $v_{\text {Crec }}$ による放熱フィンの電位変動の実測波形である。イ ンバータと平滑コンデンサを切り離しダイオード整流器の みで測定を行った。图 4(b) に示すように，放熱フィンを非 接地にしてダイオード整流器の直流出力端子に高抵抗を 2 つ直列に接続し, ダイオード整流器入力端子にY $\mathrm{Y}$ 結線高抵 抗を接続する。ダイオード整流器のコモンモード電圧 $v_{\text {Crec }}$ は，Y 結線高抵抗の中性点を基準にした場合の直流リンク 中性点の電位である。ダイオード整流器による放熱フィン の電位 $v_{H r e c}$ はダイオード整流器入力端子に接続した $\mathrm{Y}$ 結 線高抵抗の中性点を基準にした場合の放熱フィンの電位で ある。ダイオード整流器による放熱フィンの電位 $v_{H r e c}$ は ダイオード整流器のコモンモード電圧 $v_{\text {Crec }}$ と相似な波形 になる。

図 5(a) は,インバータが発生するコモンモード電圧 $v_{C i n v}$ による放熱フィンの直流リンクに対する電位変動波形であ る。図 5(b) に示すように, 放熱フィンを非接地にしてイン バータの直流リンクに直列高抵抗を，インバータ出力端子に $\mathrm{Y}$ 結線高抵抗を接続し，インバータを運転する。インバー タのコモンモード電圧 $v_{C i n v}$ は直流リンク中性点を基準に した場合のインバータ出力端子に接続した Y 結線高抵抗の 中性点の電位である。放熱フィンの電位 $v_{H i n v}$ は直流リン ク中性点を基準にした場合の放熱フィンの電位である。放 熱フィンの直流リンクに対する電位 $v_{H i n v}$ はインバータが

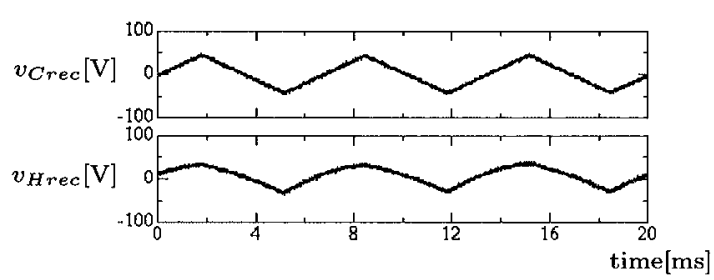

(a) Waveforms

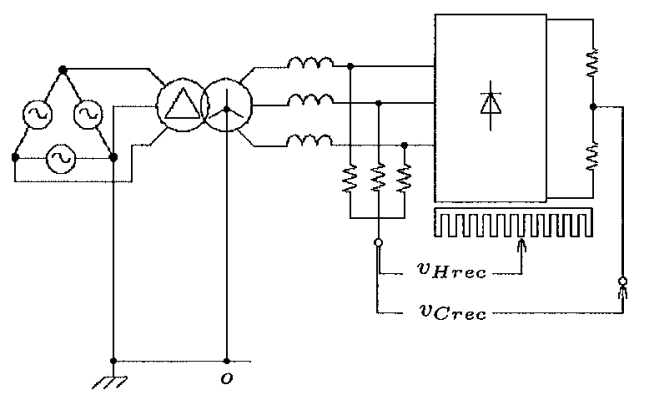

(b) Measurement Circuit

図 4 ダイオード整流器が発生するコモンモード

電圧と关れに起因する放熱フィンの電位変動

Fig. 4. Common-mode voltage generated by the diode rectifier, and the resulting heat-sink potential variation.

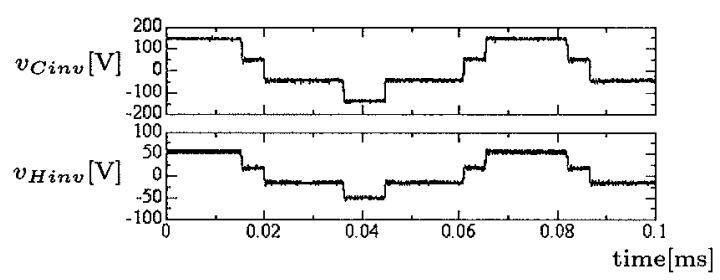

(a) Waveforms

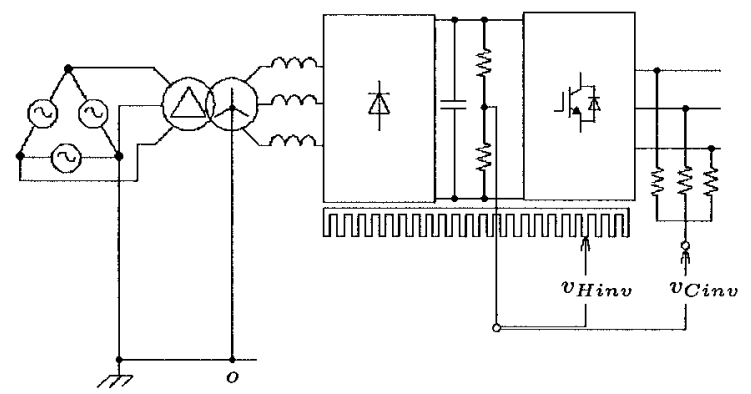

(b) Measurement Circuit

図 5 インバータが発生するコモンモード電圧と 弚れに起因する放熱フィンの電位変動

Fig. 5. Common-mode voltage generated by the inverter, and the resulting heat-sink potential variation.

発生するコモンモード電圧 $v_{C i n v}$ と相似な波形になる。放熱 フィンを接地すると，インバータが発生するコモンモード 電圧の急峻な変化によってパワーデバイスと放熱フィンの 間に存在する浮遊容量を介して高周波漏れ電流が流れる。

〈3.2〉漏れ電流の経路 図 2 と図 3 の漏れ電流の実測 波形および図 4 と図 5 の放熱フィンの電位変動波形から， 放熱フィンを接地した場合の等価回路を導出する。ここで は, 漏れ電流の経路について検討する。図 2 と図 3 から， 放熱フィンの接地によって以下のループが構成されること がわかる。 


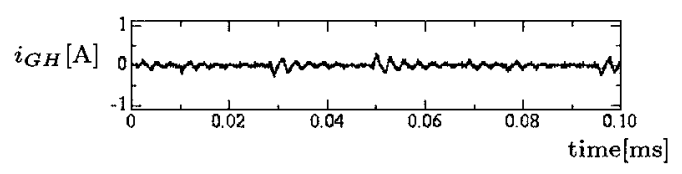

図 6 インバータとモータを直結し，モータを非 接地 , 放熱フィンを接地した場合の放熱フィンか らの漏れ電流

Fig. 6. The heat-sink leakage current when the ungrounded motor is directly connected to the inverter, and the heat sink is grounded.

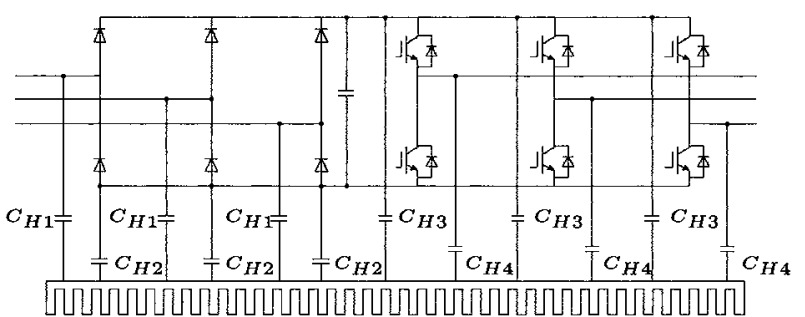

(a) Stray capacitors between the power semiconductor devices and the heat sink

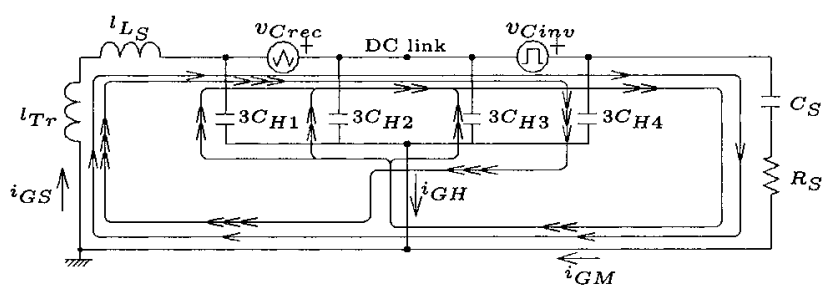

$\leftarrow$ : Loop1 $\quad$ Loop2

$l_{T r}=0.05 \mathrm{mH}, l_{L_{S}}=0.05 \mathrm{mH}, C_{S}=1 \sim 3 \mathrm{nF}, R_{S}=5 \Omega$

$3 C_{H 1}=220 \sim 370 \mathrm{pF}, 3 C_{H 2}=80 \sim 130 \mathrm{pF}, 3 C_{H 3}, 3 C_{H 4}=300 \sim 500 \mathrm{pF}$

(b) Common-mode circuit equivalent to Fig. 1

図 7 インバータとモータを直結した場合のコモ ンモードに対する等価回路

Fig. 7. Equivalent common-mode circuit when the motor is connected to the inverter directly.

$$
\begin{aligned}
& \text { ループ } 1 \\
& \text { インバータ } \rightarrow \text { モータ電力線 } \rightarrow \text { モータ浮遊容量 } \rightarrow \\
& \text { モータ接地線 } \rightarrow \text { 電源変圧器中性線 } \rightarrow \text { 三相交流リア } \\
& \text { クトル } \rightarrow \text { ダイオード整流器 } \rightarrow \text { インバータ } \\
& \text { ループ } 2 \\
& \text { インバータ } \rightarrow \text { モータ電力線 } \rightarrow \text { モータ浮遊容量 } \rightarrow \\
& \text { モータ接地線 } \rightarrow \text { 放熱フィン接地線 } \rightarrow \text { 放熱フィン } \rightarrow \\
& \text { パワーデバイスと放熱フィンの間の浮遊容量 } \rightarrow \text { } \\
& \text { ンバータ }
\end{aligned}
$$

図 6 は放熱フィンを接地し，モータを非接地にした場合の 放熱フィンからの漏れ電流 $i_{G H}$ の実測波形である。これよ り，以下のループも構成されていることがわかる。 ループ 3

インバータ $\rightarrow$ パワーデバイスと放熱フィンの間の

浮遊容量 $\rightarrow$ 放熱フィン $\rightarrow$ 放熱フィン接地線 $\rightarrow$ 電 源変圧器中性線 $\rightarrow$ 三相交流リアクトル $\rightarrow$ ダイオー ド整流器 $\rightarrow$ インバータ

〈 3. 3〉パワーデバイスと放熱フィンの間の浮遊容量 パ ワーデバイスと放熱フィンの間の浮遊容量について検討す

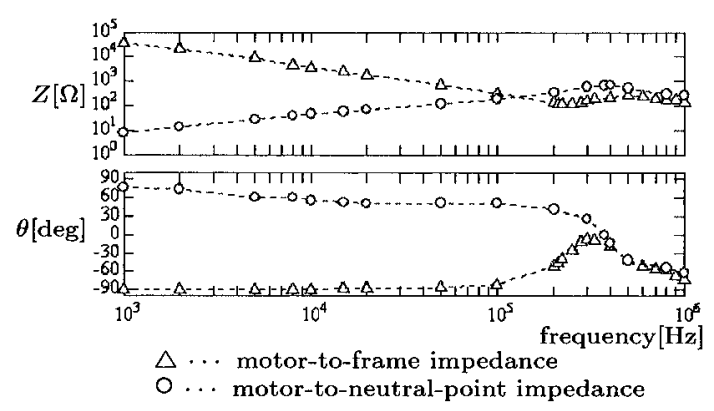

図 8 コモンモードに対するモータ巻線・モータ フレーム , モ一タ巻線・モータ中性点の間のイン ピーダンスの周波数特性

Fig. 8. Frequency characteristics of motor-to-frame impedance and motor-to-neutral-point impedance for common mode.

る。図 2 6 から，導出する等価回路は以下の条件を満たす 必要がある。

1) 放熱フィン浮遊容量は $i_{G H}$ の通るループ 2 とルー プ 3 を構成する。どちらも放熱フィンが接地された 場合にのみ構成される。

2) 汎用インバータでは,ダイオード整流器とインバー タは共通の放熱フィンを使用することが多い。

3) 図 4 から, ダイオードモジュールと放熱フィンの 間の浮遊容量はコモンモード電圧を分圧する。図 5 から，インバータモジュールについても同樣である。 図 7 は, 以上を考慮したコモンモードに対する等価回路 と電流ループである。ここで, $l_{T r}$ は電源変圧器のコモン モードに対するインダクタンス , $l_{L_{S}}$ は三相交流リアクト ルのコモンモードに対するインダクタンスである。 $C_{H 1}$ は 上側ダイオードのアノードと放熱フィンの間の浮遊容量， $C_{H 2}$ は下側ダイオードのアノードと放熱フィンの間の浮遊 容量 , $C_{H 3}$ は上側 IGBT のコレクタと放熱フィンの間の浮 遊容量 , $C_{H 4}$ は下側 IGBT のコレクタと放熱フィンの間の 浮遊容量である。ここで, 帰還ダイオードと放熱フィンの 間の浮遊容量は $C_{H 3}$ と $C_{H 4}$ に比べて十分に小さくなるの で無視する。

図 8 はコモンモードに対するモータのインピーダンス 特性を測定したものである†。図から，200 kHz 以下では $C_{S}=3 \mathrm{nF}, 500 \mathrm{kHz}$ 以上では $C_{S}=1 \mathrm{nF}$ とした。 $R_{S}$ は文 献(8) から， $R_{S}=5 \Omega$ とした。

次に ,3 $C_{H 1} \sim 3 C_{H 4}$ の值を決定する。文献 (10) から $3 C_{H 3}$ と $3 C_{H 4}$ を $300 \sim 500 \mathrm{pF}$ とする 。図 4(a) の $v_{\text {Hrec }}$ と $v_{\text {Crec }}$

\footnotetext{
$\dagger$ パワーアンプ NF 回路設計ブロック HSA4012 (DC $1 \mathrm{MHz}$, 出力 電圧 $150 \mathrm{~V}_{\mathrm{p}-\mathrm{p}}$ ，出力電流 $\left.2.82 \mathrm{~A}_{\mathrm{p}-\mathrm{p}}\right)$ を使用した。

†文献(10) では定格 $600 \mathrm{~V} ， 75$ A の IGBT モジュールが用いられて いる。弚の IGBT モジュールの 1 素子あたりのコレクタと放熱フィ ンの間の浮遊容量は $140 \mathrm{pF}$ である。本論文で使用したパワーデバイ スは定格 $600 \mathrm{~V}, 50 \mathrm{~A}$ である。文献(10) と本論文に使用した IGBT モ ジュールの定格はほぼ等しいので, IGBT モジュールと放熱フィンの 間の浮遊容量もほぼ等しいと考えられる。このため, $C_{H 3}$ と $C_{H 4}$ に は文献(10)の值を代用した。
} 


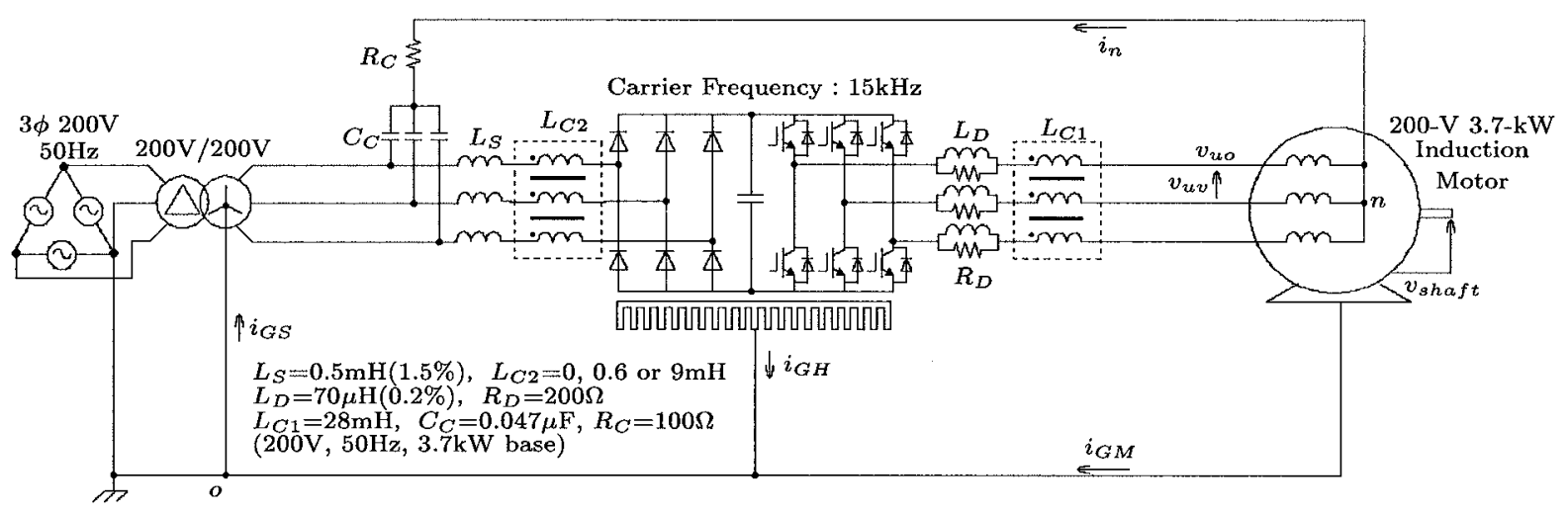

図 9 パッシブ EMI フィルタを接続した実験システム構成

Fig. 9. An experimental system configuration when the passive EMI filter is connected.

の振幅比 $\left(=34^{\mathrm{V}} / 45^{\mathrm{V}}\right)$, および図 5(a) の $v_{H i n v}$ と $v_{\text {Cinv }}$ の 振幅比 $\left(=50^{\mathrm{V}} / 150^{\mathrm{V}}\right)$ から，以下の式が成立する。

$$
\begin{aligned}
& \left.\frac{1 / 3 C_{H 1}}{1 / 3 C_{H 1}+1 / 3 C_{H 2}}=\frac{34}{45} \ldots \ldots \ldots \ldots \ldots \ldots \ldots . . . . . .3 C_{H 3}\right) \\
& \frac{1 /\left(3 C_{H 1}+3 C_{H 2}+3 C\right.}{1 /\left(3 C_{H 1}+3 C_{H 2}+3 C_{H 3}\right)+1 / 3 C_{H 4}}=\frac{50}{150}
\end{aligned}
$$

従って, $3 C_{H 1}$ と $3 C_{H 2}$ を以下のように決定できる

$$
\begin{aligned}
\therefore 3 C_{H 1} & =220 \sim 370 \mathrm{pF} \\
3 C_{H 2} & =80 \sim 130 \mathrm{pF}
\end{aligned}
$$

〈3. 4〉等価回路による考察 モータからの漏れ電流 $i_{G M}$ に含まれる $200 \mathrm{kHz}$ 成分に着目する。 $200 \mathrm{kHz}$ に対する $3 C_{H 1} / / 3 C_{H 2} / / 3 C_{H 3}$ のインピーダンスは, 電源変圧器と三 相交流リアクトルのコモンモードに対する合成インピーダ ンスに比べ十分に大きいので, $3 C_{H 1} / / 3 C_{H 2} / / 3 C_{H 3}$ を開放と して考えることができる。このためループ 1 とループ3か構 成されるので, $i_{G M}$ の $200 \mathrm{kHz}$ 成分は $3 C_{H 1} / / 3 C_{H 2} / / 3 C_{H 3}$ に流入することなく電源変圧器の中性線に流入する。ただ し，モ一タ浮遊容量 $C_{S}$ は $3 C_{H 4}$ よりも大きいので, 図 3 の $i_{G S}$ の波形からループ 3 の電流成分を認識することは難 しい。

次に，放熱フィンからの漏れ電流 $i_{G H}$ に含まれる $3 \mathrm{MHz}$ の高周波振動成分に着目する。 $3 \mathrm{MHz}$ に対する電源変圧器 と三相交流リアクトルのコモンモードに対する合成インピー ダンスはモータ浮遊容量 $C_{S}$ を経由するループのインピー ダンスに比べて大きいので, $i_{G H}$ の $3 \mathrm{MHz}$ 成分は $C_{S}$ を経 由するループ 2 の電流となる†。このため , モータからの漏 れ電流 $i_{G M}$ と放熱フィンからの漏れ電流 $i_{G H}$ には互いに逆 位相の高周波振動成分が含まれる。

\footnotetext{
${ }^{\dagger} C_{S}$ の値は $1 \mathrm{nF}$ 程度と考えられるが，正確に実測するのは難しい。 しかし，厳密に言えば $3 \mathrm{MHz}$ に対しては図 7 の等価回路が成立しな い。これは, 図 7 で無視した浮遊インダクタンスや浮遊容量が $3 \mathrm{MHz}$ では無視できなくなるためである。
}

\section{4. モータ中性線を利用したパッシブ EMIフィルタ}

〈4 1〉 システム構成＼cjkstart図 9 に, 図 1 にモータ中性線 を利用したパッシブ EMI フィルタを接続した場合の実験 システムを示す。モータ相電圧とモータ線間電圧に発生す るサージ電圧抑制のために， $L_{D} R_{D}$ の並列回路で構成した ノーマルモードフィルタ ${ }^{(8)}$ をインバータとモータ間の三相 電力線に直列に挿入している。コモンモードフィルタはイ ンバータとモータ間に接続したコモンモードチョーク $L_{C 1}$ ， ダイオード整流器と三相交流リアクトルの間に接続したコ モンモードチョーク $L_{C 2}$, 三相交流リアクトルの電源側端 子に接続した $\mathrm{Y}$ 結線コンデンサ $C_{C}$ ，および抵抗 $R_{C}$ によっ て構成されている。

図 8 から,キャリア周波数領域でのモータのコモンモード インピーダンスは $L_{M}=0.5 \mathrm{mH}$ と $R_{M}=36 \Omega$ の直列回路 と近似することができる。図 10 は, パッシブEMI フィル 夕を接続した場合のコモンモードに対する等価回路である。

〈4 2〉コモンモード電圧の抑制効果图 10 において, $150 \mathrm{~Hz}$ および $15 \mathrm{kHz}$ に対する $l_{T r}$ のインピーダンスは他 のインピーダンスに比べて十分に小さいので, これを短絡 として考える。また, 両周波数に対してモ一夕浮遊容量 $C_{S}$ のインピーダンスは $3 C_{C}, R_{C}, R_{M}, L_{M}$ の直列接続の合成 インピーダンスよりも十分に大きいのでこれを開放として 考えることができる。すなわち，インバータ $\rightarrow$ ノーマル モードフィルタ $\left(L_{D} / / R_{D}\right) \rightarrow L_{C 1} \rightarrow$ モ一タ巻線 $\left(L_{M}, R_{M}\right)$ $\rightarrow$ モ一タ中性線 $\left(R_{C}, 3 C_{C}\right) \rightarrow L_{S} \rightarrow L_{C 2} \rightarrow$ ダイオード 整流器 $\rightarrow$ インバータ，というループが構成される。こニ で, 支配的になるインピーダンスは $150 \mathrm{~Hz}$ 成分に対して は $3 C_{C}$ によるインピーダンス, $15 \mathrm{kHz}$ に対してはコモン モードチョーク $\left(L_{C 1}+L_{C 2}\right)$ によるインピーダンスである。 $150 \mathrm{~Hz}$ 成分はモータ端子に現れるが, $15 \mathrm{kHz}$ 成分はコモン モードチョーク $\left(L_{C 1}+L_{C 2}\right)$ に印加されるのでモータ端子 には現れない。このため，モータ軸電圧 $v_{\text {shaft }}$ の $150 \mathrm{~Hz}$ 成 分は除去できないが， $15 \mathrm{kHz}$ 成分を除去できる。しかし， 軸電圧の $150 \mathrm{~Hz}$ 成分のピーク值は $1 \mathrm{~V}$ 程度であるので , こ 


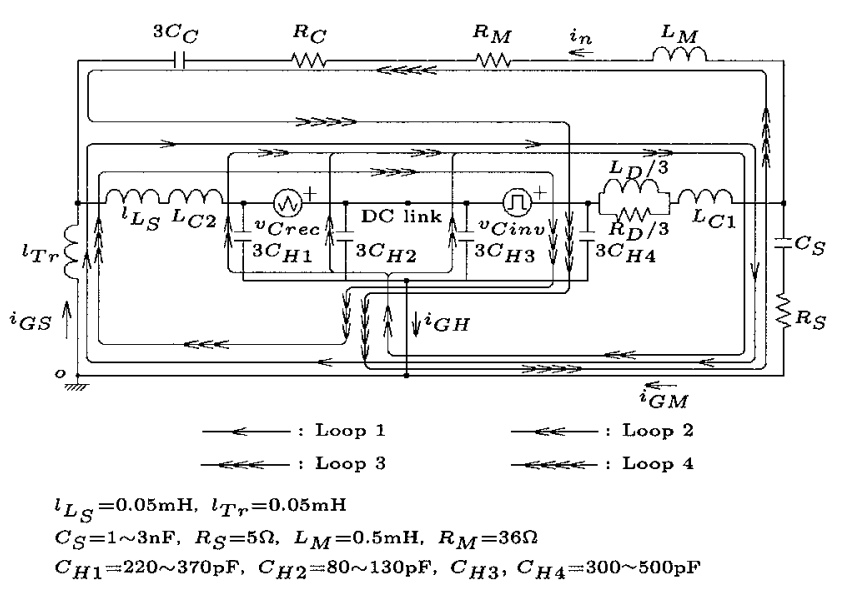

図 10 図 9 のコモンモードに対する等価回路と 漏れ電流の経路

Fig. 10. Common-mode circuit equivalent to Fig. 9, and leakage current loops.

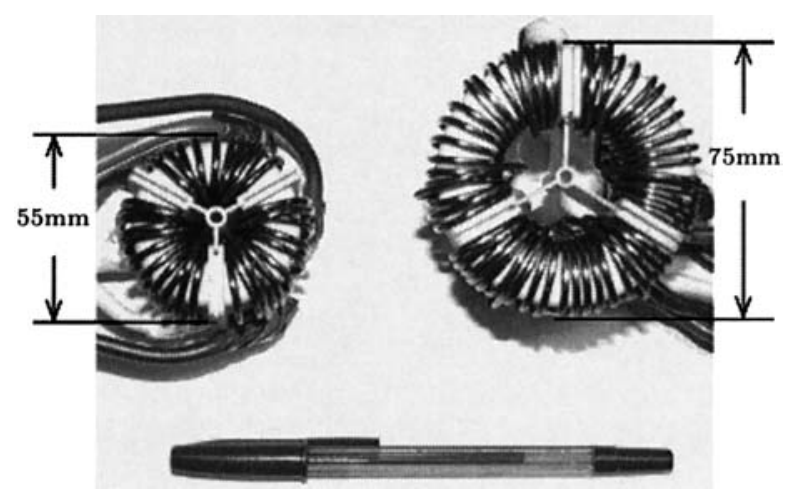

図 11 実験に使用したコモンモードチョーク $L_{C 1}$ $(=28 \mathrm{mH})$ と $L_{C 2} \quad(=9 \mathrm{mH})$

Fig. 11. Common-mode inductors used in experiment, $L_{C 1}(=28 \mathrm{mH})$ and $L_{C 2}(=9 \mathrm{mH})$.

の軸電圧か漸受電食を引き起こす可能性は十分に低いと考 えられる。

〈4 3〉 漏れ電流の抑制効果＼cjkstart重ね合わせの理からダイ オード整流器が発生するコモンモード電圧 $v_{\text {Crec }}$ を除去し て, 図 10 の電圧源としてはインバータが発生するコモン モード電圧 $v_{C i n v}$ のみを考える。まず， $L_{C 2}=0$ の場合を考え る。 $L_{C 1}$ は , ループ 1 とループ 2 の共通の経路であるモー 夕電力線に接続されている。このため,ループ 1 とループ 2 の電流を効果的に抑制することができる。しかし， $L_{C 2}=0$ の場合， $L_{C 1} \gg l_{T r}, l_{L_{S}}, L_{M}$ であることから基準電位 $o$ と 直流リンク，モータ端子がほぼ同電位になる。このことは， $3 C_{H 4}$ の両端に $v_{C i n v}$ が印加されることを意味する。关の結 果，モータ中性線を経由する新たなループ4 か構成される。

$$
\text { ループ } 4
$$

インバータ $\rightarrow 3 C_{H 4} \rightarrow$ 放熱フィン $\rightarrow$ 放熱フィ ン接地線 $\rightarrow$ モ一夕接地線 $\rightarrow$ モ一夕浮遊容量 $\left(C_{S}\right.$, $\left.R_{S}\right) \rightarrow$ モ一夕巻線 $\left(L_{M}, R_{M}\right) \rightarrow$ モ一夕中性線 $\left(R_{C}\right.$, $\left.3 C_{C}\right) \rightarrow$ 三相交流リアクトル $\rightarrow$ ダイオード整流器

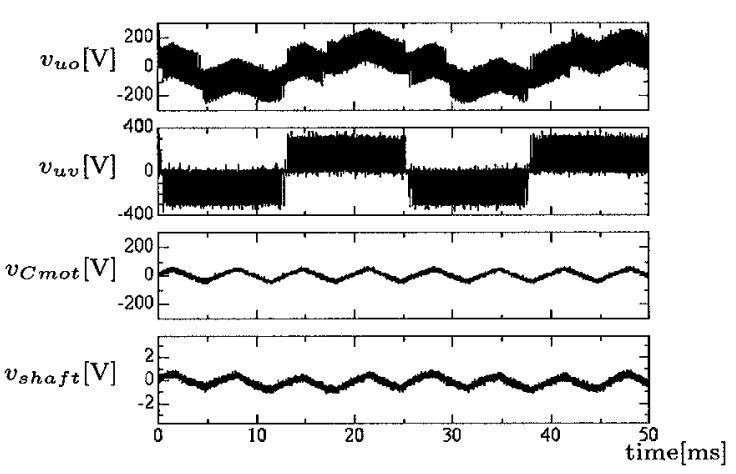

(a) Output-frequency-based time scale

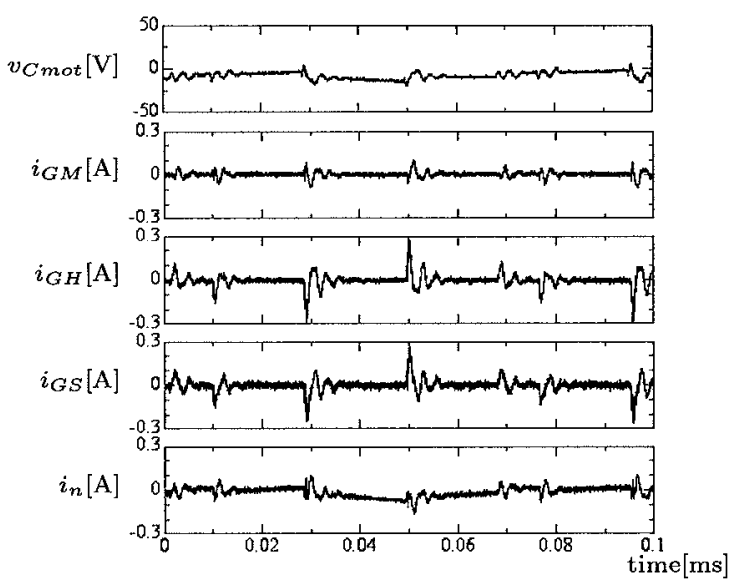

(b) Carrier-frequency-based time scale

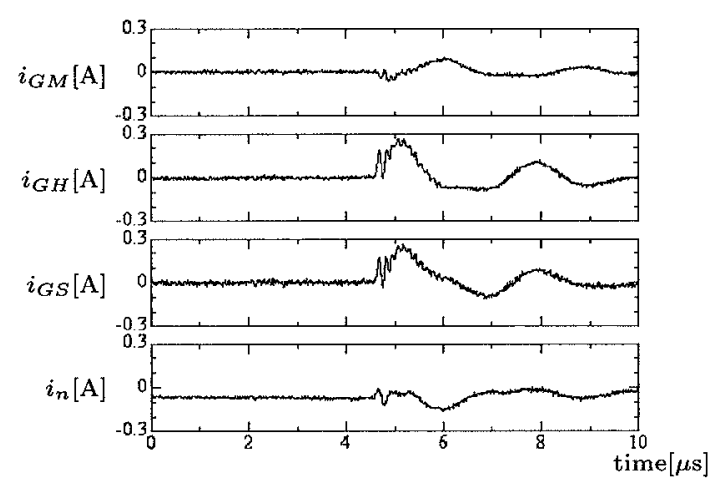

(c) Close-up waveforms of (b)

图 12 图 9 で $L_{C 2}=0$ の場合の実測波形

Fig. 12. Experimental waveforms when $L_{C 2}=0$ in Fig. 9.

$$
\text { イインバータ }
$$

図 10 に示すように,ループ 3 とループ4 の共通経路に $L_{C 2}$ を接続することによって ,ループ 3 とループ 4 を経由す る電流を抑制することができる。すなわち，モ一タからの 漏れ電流 $i_{G M}$, 放熱フィンからの漏れ電流 $i_{G H}$, 電源変圧器 中性線の電流 $i_{G S}$ のループには必ず $L_{C 1}$ または $L_{C 2}$ が存在 することになる。図 11 に実験に使用した $L_{C 1}(=28 \mathrm{mH})$ と $L_{C 2} \quad(=9 \mathrm{mH})$ の写真を示す。

\section{5. 実験結果}

以下では, インバータを 2 章と同じ条件に設定して実験 


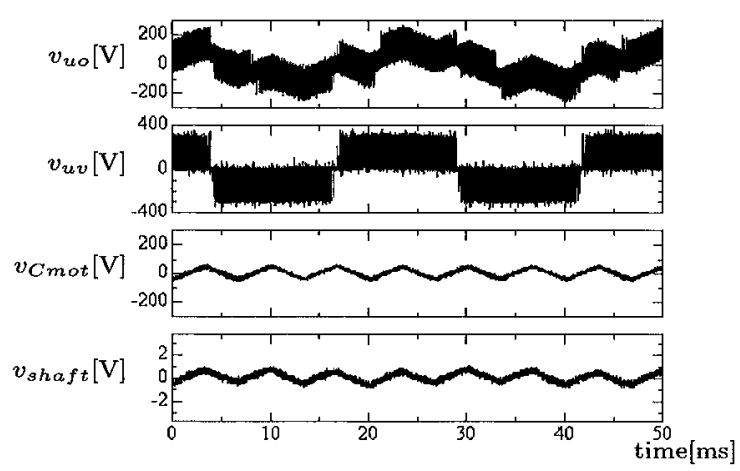

(a) Output-frequency-based time scale

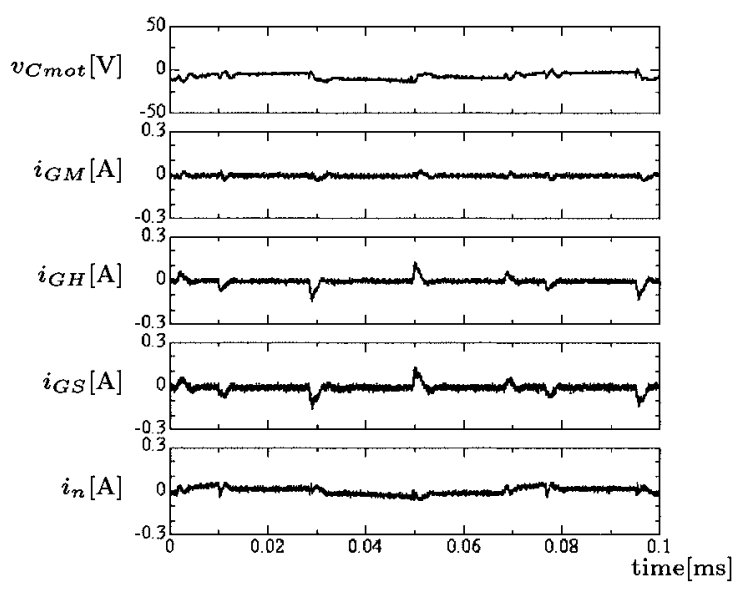

(b) Carrier-frequency-based time scale

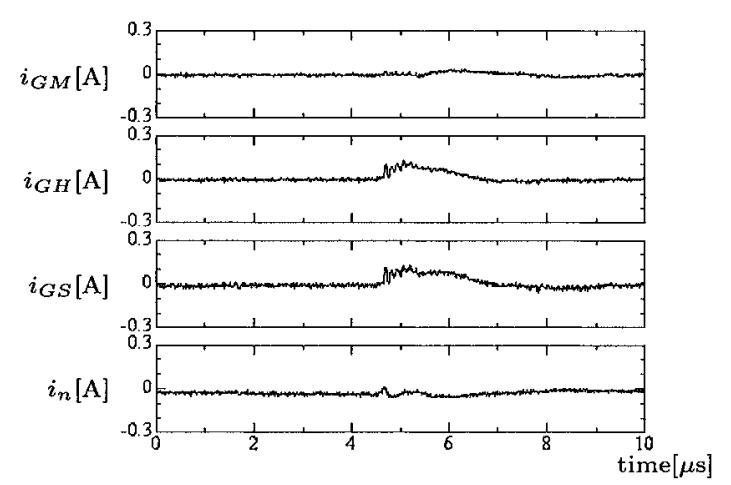

(c) Close-up waveforms of (b)

図 13 図 9 で $L_{C 2}=0.6 \mathrm{mH}$ の場合の実測波形

Fig. 13. Experimental waveforms when $L_{C 2}=0.6 \mathrm{mH}$ in Fig. 9.

を行った。図 12 に $L_{C 2}=0$ のパッシブEMI フィルタを接 続した場合の波形を示す。相電圧 $v_{u o}$ は, 図 2 と図 3 の相電 圧波形からコモンモード電圧か除去されている。また，モ一 タのコモンモード電圧 $v_{C m o t}$ からはキャリア周波数成分が 除去され, ダイオード整流器のコモンモード電圧 $v_{\text {Crec }}$ と同 じ三角波になっている。弚のため, 軸電圧からもキャリア 周波数成分か除去され, ダイオード整流器が発生するコモ ンモード電圧 $v_{\text {Crec }}$ と相似な波形になっている。 $i_{G M}$ のピー ク值は $0.1 \mathrm{~A}$ に, $i_{G H}$ および $i_{G S}$ のピーク值は $0.3 \mathrm{~A}$ に低減 されている。また，モ一タ中性線電流 $i_{n}$ の実効値は $50 \mathrm{~mA}$ であり，抵抗 $R_{C}$ での損失は $0.25 \mathrm{~W}$ でモータ定格容量より

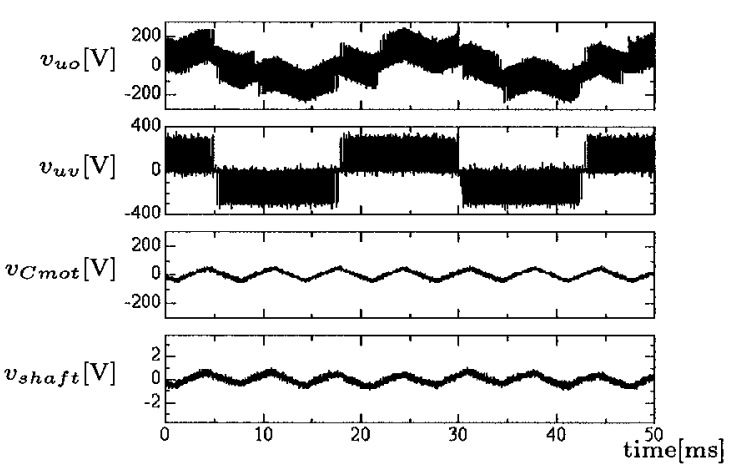

(a) Output-frequency-based time scale

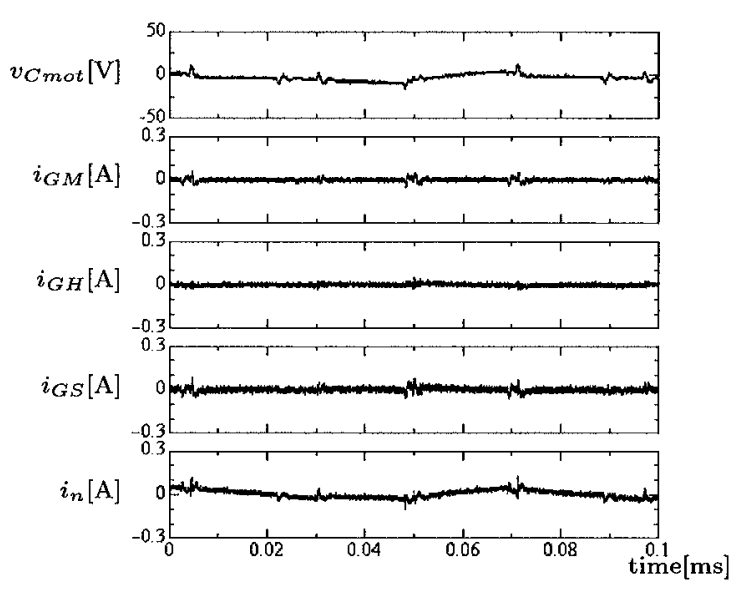

(b) Carrier-frequency-based time scale

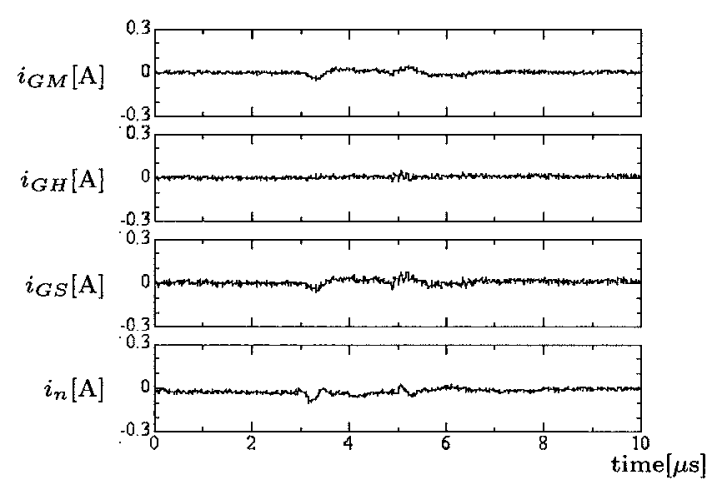

(c) Close-up waveforms of (b)

図 14 図 9 で $L_{C 2}=9 \mathrm{mH}$ の場合の実測波形

Fig. 14. Experimental waveforms when $L_{C 2}=9 \mathrm{mH}$ in Fig. 9 .

\section{表 1 パッシブ EMI フィルタによる漏れ電流 (実効値) の低減効果}

Table 1. Effect of the passive EMI filter on eliminating rms values of leakage currents from the heat sink and the motor.

\begin{tabular}{|lc|c|c|c|}
\hline & & \multicolumn{4}{|c|}{ rms values } \\
\hline & & $i_{G M}[\mathrm{~mA}]$ & $i_{G H}[\mathrm{~mA}]$ & $i_{G S}[\mathrm{~mA}]$ \\
\hline No EMI filter & (Fig. 3) & 170 & 90 & 200 \\
\hline$L_{C 2}=0 \mathrm{mH}$ & (Fig.12) & 18 & 42 & 40 \\
\hline$L_{C 2}=0.6 \mathrm{mH}$ & (Fig.13) & 10 & 22 & 27 \\
\hline$L_{C 2}=9 \mathrm{mH}$ & (Fig.14) & 9 & 8 & 13 \\
\hline
\end{tabular}

も十分に小さいのでほとんど問題にならない。図 12(c) か ら , ループ 3 とループ 4 が構成されていることがわかる。 
すなわち， $i_{G H}$ と $i_{G S}$ に同位相の成分が流れていることから ループ 3 が， $i_{G M}$ と $i_{n}$ には逆位相の成分が流れていること からループ 4 が構成されているのが確認できる。光こで, ループ 3 とループ 4 の共通経路，すなわちダイオード整流 器の交流側にコモンモードチョーク $L_{C 2}$ を接続した。図 13 に $L_{C 2}=0.6 \mathrm{mH}$ ，図 14 に $L_{C 2}=9 \mathrm{mH}$ の波形を示す。表 1 は漏れ電流の実効值をまとめたものである。当然のこと ながら， $L_{C 2}$ のインダクタンス值が大きいほど漏れ電流の 良好な抑制効果が得られる。

\section{6. 結 論}

本論文では, 電圧形 PWM インバータの放熱フィンから 接地線へ流出する高周波漏れ電流について論じた。まず， 放熱フィンを非接地にした場合と接地した場合の実測波形 から，放熱フィンやモータからの漏れ電流の流出経路を明 らかにし，コモンモードに対する等価回路を導出した。

次に，筆者らが先に発表したパッシブ EMI フィルタによ る漏れ電流抑制効果を等価回路をもとに理論的に説明した。 さらに, ダイオード整流器の交流側にコモンモードチョー クを追加することによって，モータからの漏れ電流だけで なく放熱フィンからの漏れ電流を実用上無視できる程度ま で抑制できることを実証した。

(平成 15 年 12 月 12 日受付, 平成 16 年 5 月 6 日再受付)
（1）奥山吉彦・藤井秀樹 : 「インバータ駆動誘導電動機の軸電圧」, 富士 時報, Vol.72, No.2, pp.144-149 (1999)

(2) M. Nakamura and A. Imayanagita: "Bearing Corrosion of Induction Motors", Toyo Denki Review, No.105, pp.23-32 (2000-3) (in Japanese) 中村雅憲 ·今柳田明夫 : 「誘導電動機の軸受電食」, 東洋電機技報, 第 105 号, pp.23-32 (2000)

( 3 ) T. Watanabe and M. Imai: "Current-Voltage Characteristics and Electrolytic Corrosion of Traction Motor Bearings", IEE Japan. IAS Annual Meeting, pp.23-28 (1988-8) (in Japanese) 渡邊朝紀・今井正行 : 「電気車用主電動機軸受の通電特性と電食」, 電 気学会産業応用部門全大, pp.23-28 (1988-8)

(4) S. Chen, T.A. Lipo, and D. Fitzgerald: "Modeling of Motor Bearing Currents in PWM Inverter Drives", IEEE Trans. on Industry Applications, Vol.32, No.6, pp.388-393 (1996-11/12)

( 5 ) N. Aoki, K. Satoh, and A. Nabae: "Damping Circuit to suppress Motor Terminal Overvoltage and Ringing in PWM Inverter-Fed AC Motor Drive Systems with Long Motor Leads", IEEE Trans. Industry Applications, Vol.35, No.5, pp.1014-1020 (2001-5)

(6) M.M. Swamy, K. Yamada, and T. Kume: "Common Mode Current Attenuation Techniques for Use with PWM Drives", IEEE Trans. Power Electronics, Vol.16, No.2, pp.248-255 (2001)

( 7 ) H. Hasegawa, T. Doumoto, and H. Akagi: "A Three-phase Voltage-Source PWM Inverter System Characterized by Sinusoidal Output Voltage With
Neither Common-mode Voltage nor Normal-mode Voltage—Design and Performance of a Passive EMI Filter-", T. IEE Japan, Vol.122-D, No.8, pp.845-852 (2002-8) (in Japanese)

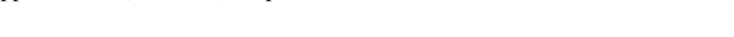
三相正弦波電圧出力 PWM インバータシステムーパッシブ EMI フィ ルタの設計と特性一」, 電学論 D, 122, 8, pp.845-852 (2002-8)

( 8 ) T. Doumoto and H. Akagi: "An Approach to Suppressing Both Shaft Voltage and Leakage Current in an AC Motor Driven by a Voltage Source PWM Inverter-A Passive EMI Filter Making Use of the Motor Neutral Line-", T. IEE Japan, Vol.123-D, No.9, pp.1057-1064 (2003-9) (in Japanese) 堂元貴史・赤木泰文 : 「電圧形 PWM インバータ駆動交流電動機の軸 電圧・漏れ電流の一抑制法一モータ中性線を利用したパッシブ EMI フィルター」, 電学論 D, 123, 9, pp.1057-1064 (2003-9)

(9) T. Doumoto and H. Akagi: "A Passive EMI Filter Characterized by the Use of the Motor Neutral Line - The case that a general-purpose inverter is directly connected to three-phase grounded voltage sources-", Proceedings of the 2003 Japan Industry Applications Society Conference Vol.I, pp.131134 (2003) (in Japanese)

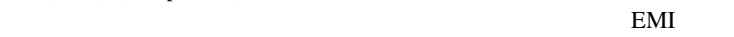
ルタ一接地系三相電源に汎用インバータを直結した場合—」, 平 15 産業応用部門大会講演論文集 I, pp.131-134 (2003)

(10) T. Shimizu, G. Kimura, and J. Hirose: "High Frequency Leakage Current Caused by the Transistor Module and Its Suppression Technique", T. IEE Japan. Vol.116-D, No.7, pp.758-766 (1996-7) (in Japanese)

清水敏久・木村軍司・広瀬 順: 「トランジスタモジュールの浮遊容 量に起因する高周波漏洩電流の解析と乥の抑制法」, 電学論 D, 116, 7, pp.758-766 (1996-7)

(11) N. Mutoh, M. Ogata, and F. Harashima: "Electric Circuit Model Suitable for Common Mode Current Paths Distributing in the Motor Drive System", T. IEE Japan. Vol.123-D, No.2, pp.131-139 (2003-2) (in Japanese) 武藤信義・小形光勝・原島文雄 : モモータ駆動形に分布するコモン モード電流経路に適した回路モデル」, 電学論 $\mathrm{D}, \mathbf{1 2 3}, 2, \mathrm{pp} .131-139$ (2003-2)

堂 元 貴 史 (学生員) 1979 年 5 月 2 日生。 2002 年 3 月東

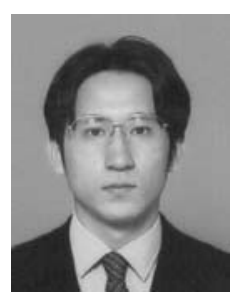
京工業大学工学部電気電子工学科卒業。2004 年 3 月東京工業大学大学院理工学研究科電気電子工学 専攻修士課程修了。同年 4 月 (株) 東芝入社, 現 在に至る。在学中はパッシブ EMI フィルタの研 究に従事。

赤 木 泰 文 (正員) 1951 年 8 月 19 日生。1979 年 3 月東京工業

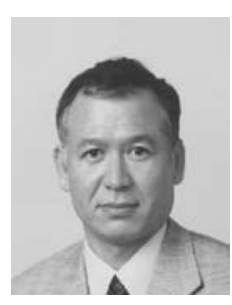
大学大学院博士課程電気工学専攻修了, 工学博士。 長岡技術科学大学助手・助教授, 岡山大学教授を経 て , 2000 年 1 月東京工業大学大学教授。パワーエ レクトロニクスの研究に従事。電気学会論文賞を 3 回 , IEEE Transactions Prize Paper Award を 3 回, IEEE IAS Committee Prize Paper Award 9 回受 賞。96 年 IEEE Fellow。98 年 IEEE IAS/PELS Distinguished Lecturer。2001 年 IEEE William E. Newell Power Electronics Award。04 年 IEEE IAS Outstanding Achievement Award。 